\title{
Securing Whiteness?
}

\section{Critical Race Theory (CRT) and the securitization of Muslims in Education}

\begin{abstract}
This article revisits Critical Race Theory and brings it's explanatory capacity to bear on the contemporary racialization of Muslims in Europe, most specifically the experience of British Muslim communities in education. The article argues that CRT can provide a theoretically fruitful means of gauging the ways in which anti-Muslim discrimination might be engendered through various strategies around securitization. In a social and political context characterized by a hyper-vigilance of Muslim educators in particular, the article concludes that applying CRT allows us to explore how a general latent whiteness is given political content through a particular racialization of Muslims.
\end{abstract}

\section{Author details:}

Dr Damian Breen, Birmingham City University, email damian.breen@bcu.ac.uk

Prof. Nasar Meer, University of Edinburgh, email nasar.meer@ed.ac.uk

\section{Introduction}

'While this appears to be an attack on a particular community, like the terrible attacks in Manchester, Westminster and London Bridge it is also an assault on all our shared values of tolerance, freedom and respect.' So stated London Mayor Sadiq Khan in the aftermath to the terrorist attack by a white nationalist on Finsbury Park Mosque. That it needs to be specified that the safety and security of Muslim Britons is coterminous with the safety and security of non-Muslim Britons, suggests that something is out of kilter with how we have come to approach the topic of security. Indeed, and while there is now a critically compelling literature on the role and function of recent approaches to security in Britain (Holmwood and O'Toole, 2017; O'Toole and Meer et al., 2016; Jackson, 20I5; Husband and Alam, 20I I; Kundani, 2009), the policy approach has remained strikingly asymmetrical in focusing upon the safety and security of the white majority, and what Muslim communities can better do to ensure this. This is despite the evidence that Muslims too are the victims of terrorism in the UK, whomever it is perpetrated by (Ismail, 2017).

In this article we seek to advance a conceptual discussion of this topic, specifically bringing to bear literatures from Critical Race Theory (CRT) to show how our 
understanding of the securitisation of Muslims would benefit from better foregrounding the role and function of whiteness. It is argued that re-visiting and utilising CRT can encourage us to think about the ways in which 'security' in Britain has become encoded in notions of civic participation and national belonging, which are in turn anchored in repertoires of whiteness. The article illustrates this by examining the policy debates about 'Fundamental British Values' and the 'Trojan Horse letter'. Each example, it is argued, illustrates how majoritarian codes are crafting strategies that in effect police Muslim mobilisations and claims-making, most apparently in our cases in the field of education. Whose security is being elevated, we suggest, flows from priorities forged in latent assumptions of whiteness.

\section{Critical Race Theory and Whiteness}

The provenance of Critical Race Theory may be traced to American legal discourse, in terms of 'a counter-legal scholarship to the positivist and liberal legal discourse of civil rights' (Ladson-Billings 1998: 7), and so foregrounds a concern with the historical, political and socio-economic position of African Americans relative to white American society. Relationality to whiteness, therefore, has always been central to CRT approaches, and specifically how this relationship is contoured by questions of 'race' and power. This is not intended as a benign description. The cornerstone of CRT approaches has been that 'racism is normal, not aberrant, in American society' (Delgado 1995, xiv). The 'normalisation' here, in Delgado's (1995, xiv) classic text Critical Race Theory: The Cutting Edge, casts racism as having formed 'an ingrained feature of our landscape, [where] it looks ordinary and natural to persons in the culture.' $\mathrm{He}$ continued:

Formal equal opportunity rules and laws that insist on treating Blacks and whites (for example) alike, can thus remedy only the more extreme and shocking sorts of injustice... Formal equality can do little about the business-as-usual forms of racism that people of color confront every day and that account for much misery, alienation, and despair.

Perhaps an under-recognised feature of this process, is the notion of a wider social desensitization to racism; possibly signalled in Delgado's description of racism as 'business as usual'. A similar set of social processes are arguably characterised by other authors in their discussion of 'everyday racism' (Essed, 1991) and the subjective negotiation of this. What we maintain is presently overlooked relates to how 'desensitisation' in turn increases the thresholds for what constitutes 'real' racism. This is perhaps what Goldberg (2006: 339) gestures to as the phenomenology of 'race' disappearing 'into the seams of sociality, invisibly holding the social fabric together even as it tears apart'. While policies promoting anti-racism continue to exist in society, they become focused on addressing unambiguous forms of racism, which incrementally normalises what ought to be considered extreme. So running parallel to observations about desensitisation, CRT scholars have long been interested in the nature and function of 'smokescreens' so called. 
There are perhaps conceptual and empirical gaps here, and the CRT literature struggles with the more ambivalent mechanics of racialization, for much of the CRT literature works with a broad brush in typically centring on the ways racial justice is 'embraced in the American mainstream in terms that excluded radical and fundamental challenges to status quo institutional practices' (Crenshaw et al 1995, xiv). This is understandable since CRT scholars do not have to work hard to elaborate how the US was founded in ways that relied on treating Black African slaves as property, and then formally emancipated African-Americans as socially, politically and legally lesser to whites (Ladson-Billings 1998: 15). American CRT theorists have been enmeshed in these debates and commenced with the implications of these historical relationships, before advancing the more normative position that a failure to question and acknowledge the function of racism is synonymous with acting to maintain the marginalised position of racialised minorities (Preston and Chadderton 2012). Much of this turns on the conviction that both tangible and intangible forms of racism are the principal means through which whiteness continues to be privileged.

Before we elaborate why this focus is useful in understanding the codification of security in Britain, specifically in terms of relationality to whiteness, it is important to register the divergences in thinking about whiteness. These correspond to its study from contexts marked by historical segregation (e.g. the US and South Africa) and elsewhere that whiteness has either (i) functioned (at least formally) as a banal repository of white majority conceptions of the given identity of societies, or (ii) ordered social relations in colonial states occupied overseas. What each reading shares in common, however, is that while whiteness was once 'seen as both invisible and normative, as being a state of 'racelessness', this is increasingly recognised only as appearing to be the case' (Rhodes, 2013: 52).

This paper is principally interested in the first kind, and proceeds with the distinction between whiteness and white individuals that has been usefully elaborated in wellknown arguments by Bonnett (1997) and Leonardo (2002) respectively. For the latter, 'whilst whiteness represents a racial discourse, the category of white people represents a socially constructed identity usually based on skin colour' (Leonardo 2002: 31). Bonnett (1997: 189) meanwhile highlights both the distinction and relationship between white people and whiteness further, while Gillborn (2005) draws on Bonnett's argument to argue it is not necessarily the case that white people as individuals inevitably reinforce whiteness any more than heterosexuals are necessarily homophobic or men are necessarily sexist. The likelihood however is that most homophobic individuals are heterosexual, and most sexist discrimination occurs against women. This point is simply that whiteness as a racial discourse does not necessarily require white people to act in the interests of reinforcing whiteness. Equally, this means is that individuals do not have to be 'white people' to actively reinforce and act in the interests of whiteness.

Building on the distinction between white people and whiteness, Preston and Chadderton (2012: 92) move to think about this in terms of white positionality but register that this is also informed by intersectionalities across social class, gender, 
sexuality and ability/disability. Thus, 'temporary ambiguities' may occur where white people are positioned on the margins of whiteness. If this is so, the critical focus on whiteness in CRT is not an assault on white people but on the socially constructed and constantly reinforced power of white identifications and interests (Gillborn 2005, 488). Furthermore, Preston and Chadderton (2012: 92) condense extensive inquiry into the distinction between whiteness and white people through arguing that the many and various ways in which the white working classes, white immigrants and white women have been positioned on the fringes of white respectability are key examples where these groups are given a liminal position within whiteness (see also Nayak, 20lI). How and in what ways therefore does this characterisation of whiteness informed by CRT help shed light on security approaches in Britain?

\section{Codifying Whiteness in Fundamental British Values}

One of the key sites for the application and development of CRT in the UK context has been within education (see Gillborn 2009; Rollock 2012; Chakrabarty 20 12; Breen 2018; Bhopal \& Rhamie 20I4). The ways in which CRT has been applied to education within the UK are well documented elsewhere, and so this article does not replicate that work. The work of Gillborn in particular has drawn attention to the outcomes of policies designed and implemented by white power holders (Gillborn 2005). These strategies are premised on the notion of maintaining inequalities at the biting point of tolerable discomfort for marginalised raclialised communities (Breen 20 I8: $5 \mathrm{I}$ ). Such policies operate under a veil of 'tacit intentionality' whereby policies which have a proven record of producing detrimental outcomes for racial minorities are advocated even in the light of evidence that they foster racial inequalities. For example, high-stakes testing, school performance tables and selection by 'ability' have remained within the British educational system for sustained periods of time in spite of the fact that research indicates that these policies have detrimental outcomes for black students (Gillborn 2005).

Work in recent years has started to apply CRT across minority ethnic groups in Britain, with emergent scholarly work on Muslim communities gaining momentum (see Housee 2012; Breen 2016; 2018). These developments raise new challenges around the scope of CRT, some of which are discussed throughout the remainder of this article. It is also important to emphasise that the enquiry here goes beyond education policy, yet this remains one of the key sites where intersections of stakeholdership in national identity for British Muslims, and strategies for securitisation have become increasingly central. Take for example the UK Government's commitment to Fundamental British Values (DfE 20I5). Clearly, issues here around 'values' and national identity are complex, not only in their relation to each other, but also in terms of the implicit parameters for stakeholdership in national identification. Applying CRT to explore the implications of FBV for British Muslims therefore requires an analytically sensitive approach. The first way to address this is to think about whiteness as a series of racialized cultural codes rather than phenotype, and specifically how these codes are bound up with particularistic sets of public policy norms. In our reading this represents one such cluster of codes whose primary 
function is to reaffirm qualities of Britishness and national identity, but in a way that has specific implications for what FBV means in particular for British Muslims.

To step back, FBV and its manifestation in schools provides an interesting case within which the relationship between religiousity and perceived risks of extremism can be explored. Furthermore, the development of FBV and the duty to promote them within schools reveals the differential ways in which the broadly Christian heritage of the wider white population has been positioned within its framework, compared with how FBV impacts on Muslims in schools. FBV is an emergent phenomenon which has been most substantively manifested in the Department for Education's (DfE) Promoting fundamental British values as part of 'Spiritual, Moral, Social and Cultural' development (SMSC) in schools (DfE 20I4). FBV actually first appears in political discourse in 20I I within the definition of 'extremism' outlined in the Government's counter-terrorism Prevent strategy:

Extremism is vocal or active opposition to fundamental British values, including democracy, the rule of law, individual liberty and mutual respect and tolerance of different faiths and beliefs. We also include in our definition of extremism calls for the death of members of our armed forces, whether in this country or overseas (Prevent 201 I: 107).

This definition of FBV would be referred to later in the 20II Teacher's standards, which identified that upholding the standards included 'not undermining the fundamental British values, including democracy, the rule of law individual liberty and mutual respect and tolerance of different faiths and beliefs' (DfE 20 I I: I4). In June 20 I4 it was stated that then education secretary Michael Gove had announced that all schools would be required to promote FBV (Wintour, 2014), with the publication of statutory guidance through SMSC following in November 2014 (DfE 20l4). The implicit connection between FBV, SMSC and Prevent was a narrative about the security dangers posed by 'Islamic radicalism', and which became solidified in the revised Prevent duty guidance (2015) that explicitly used FBV within the definition of extremism.

The relationship between Prevent and FBV assumes that the values identified as British are self-evidently inherent, uncontested and forged against the threat of prevalent Islam in the public square. There are several problems with this, not least that part of FBV advocates for 'religious tolerance' (DfE 20I I: 14). Yet FBV is clearly rooted in Prevent and fears around 'Islamic radicalism' (Prevent 2015). These fears are based on notions of increasing Islam in the public sphere as threat (see Breen 20 I8: 55), and arguably represent a clear example of religious intolerance. Aside from this contradiction, there is another problem here in the (re)establishment of particular values as being fundamentally British through FBV which would have previously been presented as shared values as part of engagement with SMSC. This affirmation of majoritarian cultural markers has thus become a default measure for identifying, by way of contrast, a definition of extremism. It is an approach that invariably cements the purpose of FBV as a strategy to police Muslim mobilisations and claims-making, perhaps most obviously 
apparent in the field of education. For example, the identification of SMSC as the primary mechanism within which the promotion of FBV has strategic and far-reaching implications, as the statutory duty to promote Fundamental British Values applies to both independent and maintained schools. In particular, the most recently Revised Prevent duty guidance for England and Wales (2015) states that:

Independent schools set their own curriculum but must comply with the Independent School Standards, which include a specific requirement to promote Fundamental British Values as part of broader requirements relating to the quality of education and to promoting the spiritual, moral, cultural and cultural development of pupils. These standards also apply to academies (other than 1619 academies), including free schools, as they are independent schools (DfE 2015: 10).

There are likely interesting reasons as to why the requirement to promote FBV extends beyond state-funded schools. Whilst there are numbers of Muslim schools in the state sector, these numbers are relatively low at 21 , compared with 158 in the independent sector (Breen 20I6: II). Thus, for FBV to be effective in policing both values promoted in state schools with high proportions of Muslim pupils and Muslim faith schools, it has to be applicable across both independent and state sectors. This ensures a totality of duty to promote FBV as a strategy for policing not only all Muslims in state schools in England and Wales, but is also Muslim schools in the independent sector.

\section{Trojan Horse and responses: FBV and Muslims in schools}

It was perhaps no coincidence that the statutory duty to promote FBV followed concerns raised by the delivery of the anonymous 'Trojan Horse letter' to Birmingham City Council in November 2013 (Kershaw 2014: 3). The letter famously made claims about an alleged plot by some Muslim groups to install governors at schools in an 'Islamic takeover plot' (Mackie 2014). Whilst a series of investigations have followed, findings appear to be less than clear cut, with the Kershaw enquiry ruling that there was 'no clear and concerted plot', but that unorthodox methods may have been used by some stakeholders. In stark contrast, in July 2014 the newly appointed Secretary of State for Education, Nicky Morgan, addressed the House of Commons with the findings of Peter Clarke's inquiry (Clarke 2014) which indicated evidence of an 'aggressive Islamist agenda' (Coughlan 2014). Within this context it is pertinent to identify that Clarke had previously been Head of Counter Terrorism at the Metropolitan Police, and was appointed as Education Commissioner despite a lack of experience in the education sector itself. Clearly, with contradicting narratives emerging around the Trojan Horse letter, it is difficult to establish a clear understanding of how far the concerns raised were realised.

In the immediate aftermath of the letter, then Education secretary Michael Gove instructed the schools in Birmingham with a majority Muslim cohort to be inspected 
(Miah 2017: 87), even though only six schools were named in the Trojan Horse letter (Clarke 2014: 107). Yet, a series of OFSTED inspections followed in a total of 21 schools which had a majority intake of Muslim pupils (Miah 2017: 89). The subsequent emphasis on FBV within Prevent was introduced with the 'Common Inspection Framework' (Ofsted 2015) from September 2015 (Miah 2017: 10I). Interestingly, the $2 \mathrm{I}$ inspections of schools in Birmingham appear to focus on section 10 of the Prevent strategy rather than the criteria present in Ofsted inspection guidelines in use at the time which had no key focus on preventing violent extremism (Miah 2017: 101), The implications of the above can be more concretely explored when looking at the role of OFSTED in the framing and reframing of activities documented in the schools inspected following Trojan Horse. For example, Oldknow School was inspected in January 2013 and rated 'outstanding' overall, and in relation to each of the four main criteria which include 'behaviour and safety of pupils' and 'leadership and management' (OFSTED 2013). Many areas of provision were praised, including an international school trip to Saudi Arabia, which was reported as a 'life changing experience' for pupils who had taken part (OFSTED 2013: 6). Furthermore, the school was also praised for using its funding to subsidise 'uniforms, trips and even large scale trips, such as the ones to Saudi Arabia, to ensure that any pupil is able to participate' (OFSTED 2013: 7).

Following the naming of the school in relation to Trojan Horse, the school was inspected again in April 20l4. This time the school was rated overall as 'inadequate', with 'behaviour and safety of pupils' and 'leadership and management' also rated as 'inadequate' (OFSTED report 2014a). The change in rating, in and of itself, raises question as to the extent to which OFSTED exercised consistency in two reports less than eighteen months apart. However, the most striking revision was manifested in concerns around the previously highly praised trip to Saudi Arabia. In particular, the use of funding to subsidise the trip was questioned on the grounds that this had been used for Muslim pupils, and that the 'choice of destination meant that pupils from other faiths were not able to join the trip' (OFSTED 20I4a: 7).

More worryingly, narratives around the Park View School raise further concerns about the consistency with which OFSTED have approached inspections following Trojan Horse. The school received a rating of outstanding in 2012, with the former Chief Inspector of Schools, Sir Michael Willshaw, praising the school's extraordinary exam success despite having $60 \%$ of its pupils qualifying for free school meals (Adams 20I4a). Following the identification of Park View school, along with two other schools in the Park View Academy Trust, the OFSTED report for 2014 rated the school as inadequate. Whilst pupil attainment and quality of teaching were rated 'good', concerns were raised about the 'behaviour and safety of pupils' and 'leadership and management' which were both rated as 'inadequate' (OFSTED 20I4b). However, a leaked report based on an inspection conducted on the 5th and 6th of March 20I4, widely circulated within the government, made a series of relatively minor recommendations which included improving systems for safeguarding and strategies to ensure students are safe from extremism (Adams 2014a). This initial report would have lowered the overall rating to 'requires improvement', but under OFSTED rules the school would have 
retained its 'outstanding' rating due to its success in other areas (Adams 2014a). However, OFSTED inspectors returned to the school unannounced on the 17th of March 2014 to conduct a second inspection which ruled the school to be 'inadequate'. The implications of this rating were that the school would be placed into 'special measures', stripped of its governors and managing trust, and handed over to new and approved management (Adams 20I4a). This would come a little more than two years after Ofsted inspectors rated the school as outstanding in all areas and praised it for its excellent academic results and inclusivity (Adams 20l4b)

The confusion around the consistency of OFSTED procedures around Park View school was met with concern by both the Park View Educational Trust (PVET) and assistant principal at the time Lee Donaghy. Writing for the Guardian newspaper in June 2014, Donaghy argued that a strongly held belief among staff was 'that the inspectors were ordered back into the school by somebody who felt that Park View had to be placed in special measures to enable the removal of Park View Educational Trust' (Donaghy, 20I4). Indeed, the initial leaked inspection report would have allowed the school to retain its governors and managing trust, but the second report ensured the removal of the Park View Educational Trust (PVET). The trust argued that there was a feeling of OFSTED 'working to a timeline and in a climate of suspicion, driven by the Trojan Horse letter and coupled with unproven allegations about Park View that had started to appear in the media' (PVET 20I4). Park View school was subsequently renamed the 'Rockwood Academy', and is now sponsored by the CORE educational trust. Interestingly, along with Park View school, the Nansen primary school and Golden Hillock were also placed into special measures following their OSTED respective inspections in April 20I4. All three were operated by the PVET, and the rating of these schools as 'inadequate' also allowed the Department for Education to remove the trust from the running of those schools and replace their governors (Adams 20l4b). Nansen primary school is now affiliated with the CORE educational trust which replaced the PVET as sponsors at Park View school. In response, Sir Tim Brighouse, a former chief education officer in Birmingham, along with 20 co-signatories, expressed serious concern around the consistency of inspection procedures following Trojan Horse. In a letter to The Guardian in 2014 Brighouse et al stated:

It is beyond belief that schools which were judged less than a year ago to be outstanding are now widely reported as 'inadequate', despite having the same curriculum, the same students, the same leadership team and the same governing body. This is uncharted territory, with Ofsted being guided by an ideology at odds with the traditional British values which schools are meant to espouse, particularly fairness, justice and respect for others (Brighouse et al cited in Adams 20l4c).

The removal of the PVET as sponsors at Park View school, the Nansen primary school and Golden Hillock was met with a statement from the organisation which contested many of the grounds on which its schools had been rated as 'inadequate'. The PVET emphasised that 'the Ofsted reports find absolutely no evidence of extremism or an imposition of strict Islamic practices in our schools' (PVET 2014). Further to this, the 
Trust argued that 'the idea of a Trojan Horse plot has created a perfect storm for individuals and organisations with agendas around education, immigration, faith, securitisation and straightforward party politics' (PVET 20I4).

Some of the wider problems around the way that Trojan Horse was handled are inherently related with contested ideas of what constitutes appropriate religious influence. All schools (whether denominational or not) are duty bound to provide Religious Education (RE) and collective worship (DFE 1994). The designation of RE and collective worship is subject to the local authority Standard Advisory Councils for Religious Education (SACREs). For non-denominational schools, RE and collective worship should be of a 'broadly Christian character' (DFE I994). However, the SACRE for Birmingham had developed a multi-faith approach since 2007, which promoted RE in line with a multiplicity of religions given the diversity of the city (Birmingham City Council 2007). It was broadly ignored in the handling of the Trojan Horse case, that the schools named in the Trojan Horse letter were adhering to locally agreed RE syllabi and provision for Islamic collective worship. However, the Clarke report identifies that the focus of the investigation was on a small number of schools which had 'converted to academy status in recent years' (Clarke 2014: 7) At no point in the Kershaw or Clarke reports is it emphasised that the schools involved were adhering to all legislative requirements and arrangements previously in place-criteria on which they had been previously praised. There are two main problems here. The first is that what is locally upheld as good practice in multi-faith provision is overlooked by the DFE. The second, is that the lack of acknowledgement of the commitment to multi-faith principles in the local SACRE itself allows for a dramatic distortion of the accusations around the extent to which appropriate religious influence may have been exceeded. If we return to the wider concerns expressed around FBV and SMSC above, Trojan Horse represents an interesting case which draws attention to the privileging of white interests through explicitly demarcating appropriate Islamic influence from appropriate religious influence more generally.

In addition to the inconsistencies around Ofsted inspections inconsistencies were also found across a series of Hearings conducted by the National College for Teaching and Leadership (NCTL) investigating individual teachers following Trojan Horse. The furore around these investigations mirrored a broader moral panic where it was reported in the media that the NCTL were looking into around 30 teachers with a total number of 100 being possibly targeted (Holmwood \& O'Toole 2017: 199). In reality, cases were actually brought against 12 individuals through a series of 4 Hearings by the NCTL (ibid.). A series of problems ensued, including concerns that witness statements which had been given to the Clarke report had been significantly longer and contained evidence which was favourable to the defence, but which had been omitted from both the report and statements elicited by the NCTL (Holmwood \& O'Toole 2017: 20I). Procedural irregularities continued, with Hearing 2 being quashed under a High Court appeal, in part due to failure to disclose evidence which was presented in Hearing I (Holmwood \& O'Toole 2017: 200). The collapse of Hearing I followed on the grounds of irregularities which represented an 'abuse of the process 
which is of such seriousness that it offends the Panel's sense of justice and propriety' (Holmwood \& O'Toole 2017: 202). This marked the end of the NCTL investigations, with only I teacher sanctioned with a 5 year ban, and the reasons given for the Panel to discontinue the main hearing make up 28 pages of text, alongside a Note submitted by the NCTL which acknowledged that the defence lawyers had been 'deliberately misled' (ibid). These examples demonstrate the ways in which Muslims have been differentially targeted through various different mechanisms of state apparatus around securitisation. But they also demonstrate that Muslims have been afforded differential access to due process through formal channels which have consistently facilitated strategic efforts to manipulate outcomes in the wake of Trojan Horse.

\section{FBV and Interest Convergence}

What the discussion thus far helps make apparent are the ways that strategies of securitisation have implications for the marginalisation of Muslim groups in Britain. If this process occurs at primarily the macro level, where such strategies are bound up with national protection, then a question remains around the interests of British Muslims within this dynamic. Specifically, the extent to which British Muslims figure as stakeholders in this process is missing, and assume indifference towards the interests of Muslims as requiring security too. Whilst the interests of British Muslims may well be entirely convergent with those of white English groups, the framing of approaches to securitisation arguably ignores this convergence. This process inevitably raises questions about the neutrality behind strategies for securitisation.

Derek Bell (1980) once argued that advances in US civil rights were concessions that aligned not with the objectives of civil rights, but with US propaganda efforts with the Soviet Union. It was an assertion empirically explored by Dudziack (200I) who pointed to newly available records of how the Supreme Court considered the cold war implications of their rulings in favour of civil rights cases. For CRT scholars, these concessions also came with a wider set of implicit demands, as Delgado (2003:129) put it, that 'African Americans and other people of colour...embrace anti-communism, fight in foreign wars, and purge themselves of radical elements'. For Bell, Delgado, Dudziack and others, the interests of minority ethnic groups were advocated or advanced only in so far as they converged with the interests that brought gains for white groups. What is overlooked here is that interest convergence should be read solely in terms of conventional social policy, but also as a means of supporting discursive facets of systems of injustice.

The UK has seen a great deal of new policy and practice informed by a concern with Muslim radicalism. Currently, the Prevent Duty requires frontline personnel to be vigilant for signs of increased religiosity, as though this were a reliable indicator of tendencies toward violence. As O'Toole (2015) summaries, public sector workers are being asked to interpret signs of radicalisation, based on a weak and contested understanding of radicalisation. One of the keys ways that this has been manifested is through recent revisions to Prevent. In 201I, the Prevent strategy was expressly 
revised to target "non-violent extremism" on the theory that it is the precursor to terrorist activity (OSJI 2016: 33). Furthermore, the Revised Prevent Duty Guidance requires specified authorities, which includes schools, to prevent individuals from being drawn into both non-violent and violent extremism (for a full list of 'specified authorities' see Schedule 6 of the Counter-Terrorism and Security Act, 2015). It has been argued that the focus on 'pre-criminality', non-violent 'extremism', and opposition to 'British values' is fundamentally flawed (OSJI 2016: 34) for a series of reasons but two are most relevant here. Firstly, the success of the strategy is predicated on the assumption that its use can effectively determine whether an individual will commit a terrorist act in the future (ibid). Secondly, and related closely to this, the duty to report on 'pre-criminality' gives legal backing to potentially discriminatory determinations of 'extremism' by frontline professionals.

These concerns have indeed played out, with a significant number of children and young people being referred to the Government's de-radicalisation 'Channel' programme. For example, in $2015 / 1656 \%$ of referrals were for individuals under 20 , with the education sector making the most referrals $(2,539)$ accounting for $33 \%$ of all referrals that year (Home Office 2017: 4). 65\% (4,997) were referred for concerns related to Islamist extremism with $36 \%$ of those referred in $2015 / 16(2,766)$ leaving the process requiring no further action. $3,793(50 \%)$ were signposted to alternative services and I,072 (14\%) were deemed suitable, through preliminary assessment, to be discussed at a Channel panel (Home Office 2017: 4). The vast majority (76\%) of those discussed at a Channel panel were regarding Islamic extremism. For 2015/16 $38 \mathrm{I}$ individuals received channel support following a channel panel with $96 \%$ of these (365) subsequently leaving the process and $4 \%$ ( 16 individuals) receiving continued support (Home Office 2017: 4). Of those who left the process, $83 \%$ were identified as having their risk of being drawn into terrorism being 'significantly reduced' (Home Office 2017: 4). These figures could be taken to indicate that this process successfully rehabilitates individuals who would have otherwise committed terrible acts. But they could also be taken to demonstrate just how widely the net is cast when using tentative notions of 'pre-criminal' behaviour, and just how vague the criteria for referral is, given that only $4 \%$ of those who received support following a Channel panel required ongoing support. For 2015/16, only 16 individuals required ongoing support out of a total of $763 \mathrm{I}$. Expressed as a percentage this amounts to $0.2 \%$ of all referrals, a statistic which might as easily be explained by a lack of rationale for $99.8 \%$ of referrals as by potential risk of committing a crime.

A number of case studies around referrals to the Channel programme give reason for concern. For example, in one instance a mother was called in to a nursery to discuss a picture their child had drawn of its father cutting a cucumber. When asked what the picture was of, the child was misinterpreted as saying 'cooker bomb' when attempting to say 'cucumber' (OSJI 2016: 72). The child's mother was then repeatedly told by the nursery manager that she had been referred to Channel, and that there was no opportunity to discuss and resolve the matter in-house adding 'you can prove yourself innocent. They might not take your kids off you' (OSJI 20I6: 72). After refusing to sign 
the form and seeking legal advice, it transpired that she had not in fact been referred, but the process left her feeling 'like an outsider', and targeted as a result of being Muslim (OSJI 2016: 73).

In another case a Muslim kitchen staff member in one school drew attention to other kitchen staff neglecting the designation of utensils for serving halal food. This resulted in accusations from other kitchen staff that their Muslim colleague had said that she 'supported ISIS' and she was subjected to a disciplinary panel and subsequent appeals panel with the school and the Local Authority. Whilst the accused member of staff won the decision at the appeals panel and was reinstated, she was still issued with a 'first warning' and had not returned to work in the five months following this (OSJI 2016: 68). This brings us back the discursive positioning of British Muslims as stakeholders within strategies for securitisation. How do their interests figure and to what extent are they afforded legitimacy?

In the aftermath of the attack in Manchester on the $22^{\text {nd }}$ of May 2017, various media sources drew attention to emergent accounts of Muslims contacting authorities over a period of time about radicalisation in Manchester. Mohammed Shafiq, Chief Executive of the Manchester-based 'Ramadhan Foundation', spoke specifically about anxieties members of the Muslim community had raised about Salman Abedi: 'people in the community expressed concerns about the way this man was behaving and reported it in the right way using the right channels', but 'did not hear anything since' (Mendick et al 2017). Friends of Abedi also allegedly became so worried about his behaviour that they individually called the counter-terrorism hotline five years ago and again last year; they had been concerned that 'he was supporting terrorism' and had expressed the view that 'being a suicide bomber was ok' (Mendick et al 2014). A member of the close-knit Libyan community in South Manchester also stated that Abedi had been banned from Didsbury Mosque after confronting an Imam who was delivering an antiextremism sermon (Mendick et al 2014). The Mosque reported Abedi to the authorities and he had subsequently been placed on a 'watch list' because of his extremist views (Mendick et al 20l4).

Muslim community engagement with counter-terror processes and procedures represents an example of interest convergence as British Muslims had clearly exercised serious concern as stakeholders in national security. Counter to the subtext of strategies like FBV, this represents an example of increased Islamic influence actually informing action around maintaining convergent interests around the protection of the public from violent extremism. There is evidence to suggest that Muslims were concerned about Abedi over a period of at least five years. Furthermore, the 2017 special report by the Intelligence and Security Committee of Parliament identified a range of areas where MI5 and counter-terrorism police could have taken more action (see ISC 2017). The question to ask at this point is whether or not more substantive action would have been taken had the voices informing concern been those of white, nonMuslim citizens. 
The examples of innocent Muslims caught up in the Prevent strategy would suggest that this would likely have been the case, and clearly requires further and substantive empirical research. However, the framing of securitisation as a manifestation of ostensively white majority interests raises questions about the impact of racialisation on the legitimacy of voices in discourses around securitisation. Not only is securitisation principally associated with protection from Muslims, but in spite of active engagement, it still seems that concerns raised by Muslims have not been treated with urgency and legitimacy. Paying attention to the discursive features overlooked by CRT leads us to understand the positioning of Muslim voices as peripheral to those of 'real' stakeholders in securitisation. This example clearly demonstrates the intersection of interests around securitisation across white majority and Muslim minority groups. The intersection of these interests reveal differential expectations for Muslim and white English groups around the purpose of securitisation. Whilst public policy discourses around securitisation are firmly rooted in notions of protection for citizens, the wider expectations for Muslims in securitisation appears to be less about being protected and more about being active in engaging with counter-terror processes. This demonstrates a privileging of perceptions of security among white citizens at the expense of full stakeholdership in protection for Muslims.

\section{Conclusion: Securing Whiteness}

In a typically perceptive discussion of trajectories in the scholarship of whiteness studies, Garner (2017: 1585) argued that 'the sword Damocles hanging over the scholar of whiteness is the question of how to wrestle its meanings into connection with other social relationships... and remaining true to the first wave origin: make white supremacy visible' (original emphases). This article is subject to these dynamics too, in so far as it has aimed to explore the ways in which reinvigorations of whiteness sit at an interplay between strategies around securitisation and what this means for Muslims in Britain. We have argued that the relationship between FBV and definitions of 'extremism' in the Prevent strategy has had profound implications for the monitoring and regulating of Muslim mobilisations in Britain.

The literature on Critical Race Studies allows us to see how FBV represents a majoritarian set of cultural markers, which assume a self-evident and inherent nature, uncontested and forged against the threat of prevalent Islam in the public square. For Muslims, misalignment with these markers has specific implications and specific risks are faced which do not apply to other Britons, most notably that of being associated with, affiliated with, or suspected of 'extremism'. In particular, one of the contributions made in this article has been to explore how the statutory duty to promote FBV manifests a particular approach for regulating Muslims in educational settings. The Trojan Horse hoax represents the starkest example of this, and further cemented public anxieties toward Muslims in the wider public consciousness. Further to this, the series of events around Trojan horse and the subsequent OFSTED inspections and reports discussed in this article demonstrate that anxieties around extremism exist on two levels - anxieties around extremism itself; and anxieties within 
regulatory authorities around being seen to have 'missed' a possible cause for concern relative for Prevent, SMSC or FBV. The case of Park View School and apparent inconsistencies in a series of OFSTED reports and inspections at the school seems to embody this process most substantively among the observations presented in this article.

Then, there is the question of what all of the above means for Muslims in Britain and their stakeholdership in national security. A series of processes have led us to argue here that securitisation, as it has played out in the British context, has an innate relationship with whiteness and resurgences in nationalist discourse in the English public space in particular. It goes without saying that there is clearly a need for further research in this area, but the theoretical considerations and empirical observations discussed in this article reveal how a complex interplay of public discourse, state strategy and implementation suggest that securitisation is about 'securing whiteness' in a series of ways.

Whilst the surface narrative suggests an impartial strategy for preventing violent extremism, our reading of how this is playing out reveals a far subtler and discursive effort to delineate 'British' and Muslim which has consequences for the latter. FBV is a set codes whose primary function is to reaffirm qualities of Britishness and national identity in a way that has specific implications for British Muslims. There is undoubtedly an implicit narrative around the threat of 'Islamic radicalism' that connects FBV, SMSC and Prevent. These efforts to reify Britishness have heralded a dynamic in which the reification of Britishness occurs where the interests of British Muslims as stakeholders in both nation and national security are diminished. The danger here is that the outcomes of these strategies could sustain a focus on issues around the fringes of radicalisation, rather than allowing a meaningful exploration for how the dynamics of these related strategies might contribute to feeling of alienation for Muslims as stakeholders in securitisation themselves.

\section{References}

Adams, R. (20/4a) 'Ofsted inspectors make U-turn on 'Trojan Horse' school, leak shows', The Guardian, $30^{\text {th }}$ May 2014, available at: https://www.theguardian.com/education/20/4/may/30/ofsted-u-turn-trojan-horsepark-view-school-leak last accessed: 15/08/2017

Adams, R. (20l4b) 'Six Birmingham schools face censure by Ofsted after Trojan Horse inquiry', $\quad I^{\text {st }} \quad$ June 2014, available at https://www.theguardian.com/education/2014/jun/0I/six-birmingham-schools-ofstedspecial-measures last accessed: 15/08/2017

Adams, R. (20I4c). 'Education experts voice fury over Ofsted's 'Trojan Horse' schools inquiry', The Guardian, $3^{\text {rd }}$ June 2014, available at 
https://www.theguardian.com/education/2014/jun/03/education-experts-ofstedtrojan-horse-birmingham-schools last accessed: 15/08/20I7

Bell, D. (1980) 'Brown v. Board of Education and the Interest-Convergence Dilemma', Harvard Law Review, 93, 518-533.

Bhopal, K. \& Rhamie, J. (2014) 'Initial teacher training: understanding 'race', diversity and inclusion', Race Ethnicity and Education, Vol. 17, No. 3, pp. 304-325

Birmingham City Council (2007): The Birmingham Agreed Syllabus for Religious Education, Birmingham: Birmingham City Council

Breen, D. (2018) Critical Race Theory, Muslim Schools and Communities: Faith Schooling in Islamophobic Britain? London: Palgrave-Macmillan

Breen, D. (2016) 'Critical Race Theory, policy rhetoric and outcomes: the case of Muslim schools in Britain, Race Ethnicity and Education, http://dx.doi.org/l 0.1080//36/3324.20/6.1248828

Clarke, P. (2014) Report into allegations concerning Birmingham schools arising from the 'Trojan Horse' letter, London: Her Majesty's Stationary Office

Coughlan, S. (2014). "'Disturbing" findings from Trojan horse inquiry', BBC News, $22^{\text {nd }}$ July 2014, available at http://www.bbc.co.uk/news/education-2841990I last accessed: $15 / 08 / 2017$

Crenshaw, K,. Gotanda, K., Peller, G., and Thomas, K. Eds. (1995) Critical Race Theory: The Key Writings that Formed the Movement. New York: The New York Press

Delgado, R. (Ed.). (1995). Critical Race Theory: The cutting edge. Philadelphia: Temple University Press.

DfE (20I4). Promoting fundamental British values as part of SMSC in schools: Departmental advice for maintained schools, London: Department for Education

DfE (2015) The Prevent Duty: departmental advice for schools and childcare providers, London: Department for Education

Donaghy, L (20I4). 'Ofsted's slur on the Muslim community of Park View School', The Guardian, $\quad 9^{\text {th }} \quad$ June 2014 available at https://www.theguardian.com/commentisfree/2014/jun/09/ofsted-slur-muslim-parkview-school-values-extremism last accessed: 15/08/2017

Essed, P. (199|) Understanding Everyday Racism: An Interdisciplinary Theory. Amsterdam: University of Amsterdam. 
Goldberg, T. G. (2006) 'Racial Europeanization', Ethnic and Racial Studies, 29 (2), pp. 332-64

Garner, S. (2017) 'Surfing the third wave of whiteness studies: reflections on Twine and Gallagher', Ethnic and Racial Studies, 40 (9), I 582-I 597.

Hage, G. (1998) White Nation: Fantasies of White Supremacy in a Multicultural society. Annandale: Pluto Press.

Hammid, S. (2007) 'Islamic Political Radical Radicalism in Britain: The Case of Hizb-ut Tahrir', in T. Abbas (Ed), Islamic Political Radicalism: A European Comparative. Edinburgh: Edinburgh University Press.

Hewitt, R. (2005) White Backlash and the Politics of Multiculturalism, Cambridge: Cambridge University Press

Holmwood, J. and O'Toole, T. (2017) Countering extremism in British Schools? The truth about the Birmingham Trojan Horse Affair. Bristol: Policy Press.

Husband, C. and Alam, Y. (20II) Social Cohesion and Counter-Terrorism: A Policy Contradiction? Bristol: Policy Press

Hussein, E. (2007) The Islamist. London: Penguin.

ISC (2017) The 2017 Attacks: What needs to change? Intelligence and Security Committee of Parliament, London: HMSO

Ismail, S. (2017) 'East London acid attack: When Muslims are the victims, we refuse to call it terrorism', Independent, http://www.independent.co.uk/voices/east-london-acidattack-terrorism-islamophobia-a7817466.html

Jackson, R (2015) 'The epistemological crisis of counterterrorism', Critical Studies on Terrorism, 8(I): 33-54.

Kershaw, I. (2014). Investigation report: Trojan Horse letter - report of lan Kershaw of Northern education for Birmingham City Council in respect of issues arising as a result of concerns raised in a letter dated 27November 2013, known as the Trojan Horse letter

Kundnani, A. (2009) Spooked: How not to prevent violent extremism. London: Institute of Race Relations.

Ladson-Billings, G. (1998) 'Just what is critical race theory and what's it doing in a nice field like education?', Qualitative Studies in Education, I I(I), 7-24. 
Mackie, P. (20I4). "'Islamic takeover plot" in Birmingham schools investigated', BBC News, $7^{\text {th }}$ March 2014, available at http://www.bbc.co.uk/news/uk-england-birmingham26482599, last accessed: 15/08/2017

Meer, N. (2013) 'Race, Culture and Difference in the Study of Antisemitism and Istamophobia', Ethnic and Racial Studies, 36 (3), 385-398.

Meer, N. (2015) 'Multinationalism, Multiculturalism and Scottish Nationhood', Ethnie and Racial Studies, $38(9), 1477-1496$.

Meer, N. \& Modood, T. (2009): 'Refutations of racism in the 'Muslim Question', Patterns of Prejudice, 43 (3-4): 335-354

Mendick, R. Rayner, G. Evans, M. \& Dixon, H. (2017). 'Security services missed five opportunities to stop the Manchester bomber', The Telegraph, $6^{\text {th }}$ June 2017 , available at http://www.telegraph.co.uk/news/2017/05/24/security-services-missed-fiveopportunities-stop-manchester/ last accessed: I5/08/2017

Nayak A (20I I) Geography, race and emotions: Social and cultural intersections. Social and Cultural Geography 12(6): 548-62.

OFSTED (2013). School report: Oldknow Academy (20/3), Manchester: Office for Standards in Education, Children's Services and Skills

OFSTED (20I4a). School report: Oldknow Academy (20/4), Office for Standards in Education, Children's Services and Skills

OFSTED (20l4b). School report: Park View school (20/4), Office for Standards in Education, Children's Services and Skills

O'Toole, T., and Meer, N., DeHanas, D., Jones, S., and Modood, T. (2016) 'Governing through Prevent? Regulation and contested practice in state-Muslim engagement', Sociology, 50 (I): 160-177

O'Toole, T, (2015) 'Prevent: from 'hearts and minds' to 'muscular liberalism". Public Spirit, http://www.publicspirit.org.uk/prevent-from-hearts-and-minds-to-muscularliberalism/

Prevent (20I I). Prevent strategy, London: HMSO

Preston, J. and Chadderton, C. (2012) 'Rediscovering 'Race Traitor': towards a Critical Race Theory informed public pedagogy', Race, Ethnicity and Education, I5, I, 85-100

PVET (20I4). Statement from Park View Educational Trust on Ofsted reports on Park View, Golden Hillock and Nansen schools, $9^{\text {th }}$ June 2014, Birmingham: Park View Educational Trust 
Rhodes, J. (2013) 'Remaking whiteness in the "postracial” UK, in N. Kapoor, V. S. Kalra and J. Rhodes (eds) The State of Race. Basingstoke: Palgrave

Saggar, S. (2009) 'Boomerangs and Slingshots: Radical Islam and Counter-Terrorism Strategy', Journal of Ethnic and Migration Studies, 35 (3),

Wintour, P. (20I4). 'Michael Gove wants “British Values” on school curriculums', The Guardian, $9^{\text {th }} \quad$ June $2014, \quad$ available https://www.theguardian.com/education/2014/jun/09/michael-gove-british-valuescurriculum, last accessed: 15/08/2017

\footnotetext{
i http://metro.co.uk/2017/06/19/sadiq-khan-leads-calls-for-calm-in-wake-of-finsbury-park-terror-attack$6718247 /$ We are grateful to Claire Alexander for making us aware of this reference.
} 